\title{
Sistem Monitoring dan Evaluasi Pengelolaan Program Studi di Institusi Pendidikan Tinggi
}

\author{
C A Wijaya*1 \\ ${ }^{1}$ PT. Astra International, Tbk \\ E-mail: conanaditya16@gmail.com \\ Masuk: 25 Agustus 2018, direvisi: 26 Agustus 2018, diterima: 26 Agustus 2018
}

\begin{abstract}
Abstrak. Seiring dengan perkembangan zaman dan meningkatnya kebutuhan membuat proses bisnis semakin kompleks, tak terkecuali di bidang pendidikan. Banyaknya informasi dan sumber daya yang dimiliki oleh institusi pendidikan tinggi khususnya pada tingkat program studi akan membuat pengelolaan yang ada menjadi rumit. Untuk itu, perlu dilakukan proses monitoring dan evaluasi demi menjamin validitas transaksi yang ada. Pada penelitian ini, penulis membangun sebuah sistem yang dapat melakukan monitoring dan evaluasi terhadap pengelolaan yang ada di program studi. Sistem ini dibangun berdasarkan poin-poin penilaian yang terdapat pada borang akreditasi. Poin-poin penilaian tersebut nantinya digunakan oleh pihak program studi sebagai tolak ukur dari kualitas sumber daya yang ada. Caranya adalah dengan mengkomparasikan data-data mentah yang terdapat pada borang akreditasi dengan rumus-rumus yang terdapat pada penilaian borang akreditasi. Hasil komparasi tersebut akan digunakan oleh pihak program studi dalam melihat performa sumber daya yang ada dalam satu tahun. Sistem ini berbasis web dan dikembangkan dengan bahasa pemrograman PHP dan menggunakan sistem pengelolaan basis data MySQL.
\end{abstract}

Kata kunci: monitoring; evaluasi; borang akreditasi; penilaian

\begin{abstract}
The more technology and needs develop in the society, the more complicated business process will be, even for education. Information and sources owned by educational institutions especially on study program level will create a chaos in the administration process. Therefore, monitoring process and evaluation are necessary to be conducted in order to guarantee the existing transaction validity. In this research, the researcher builds a system that can supervise and evaluate study program's administration. This system is built based on assessment points written in the accreditation forms. These assessment points will later be used by the study program as a measurement of existing source's quality. The method is by comparing primary data in accreditation forms with some formulas in the form's assessment. The comparison results will then be applied to see the source's performance in one year. This system is built based on the web with the PHP programming language and uses a MySQL Data Base Management Systems (DBMS).
\end{abstract}

Keywords: monitoring; evaluation; accreditation forms; assessment

\section{Pendahuluan}

Dengan semakin kompleksnya proses bisnis yang terjadi di suatu perusahaan, maka hal ini juga akan memicu munculnya berbagai resiko baru yang akan menghambat proses bisnis yang ada. Hal ini 
dikarenakan pesatnya pertumbuhan teknologi dan infrastruktur yang ada. Dengan begitu kebutuhan dan keinginan pasar akan meningkat pula. Tentu hal ini tidak dapat dipandang sebelah mata karena dapat mengakibatkan dampak negatif yang cukup signifikan. Fenomena diatas membuat berkembang pesatnya sistem informasi dan menjadi kebutuhan yang bersifat strategik di banyak perguruan tinggi Indonesia[1]. Secara tradisional, proses audit terhadap transaksi yang ada umumnya dilakukan pada akhir transaksi, yaitu saat semua transaksi sudah selesai. Hal ini dikarenakan proses audit tidak lazim untuk dilakukan pada saat transaksi sedang berjalan [2]. Namun hal ini belum cukup, karena dengan mengecek keberhasilan suatu transaksi hanya dari hasil akhirnya saja tidak akan dapat menjawab secara lengkap masalah terkait bagaimana suatu transaksi dapat berjalan secara baik atau tidak.

Oleh karena itu, demi menjamin validitas transaksi yang ada perlu dilakukan tindakan yang disebut monitoring dan evaluasi terhadap transaksi yang ada. Monitoring dapat didefinisikan sebagai suatu kegiatan yang dilakukan secara terus menerus dan bersifat utuh dari manajemen perusahaan yang isinya adalah penilaian yang bersifat sistematis terhadap kemajuan suatu pekerjaan [3]. Monitoring dapat dikatakan sebagai suatu proses pencatatan dan pengumpulan informasi terhadap tugas-tugas projek secara periodik. Monitoring berguna untuk melihat dan memantau perkembangan suatu pekerjaan atau transaksi yang sedang berjalan.

Sedangkan evaluasi dapat didefinisikan sebagai proses pengumpulan informasi yang sistematis yang nantinya akan digunakan sebagai pengetahuan baru dalam mendukung keputusan yang ada [4]. Evaluasi adalah proses yang kompleks, yang dikaitkan dengan nilai tertentu sesuai dengan kriteria dan standar tertentu[5]. Proses evaluasi akan mencatat dan menyusun hasil dari monitoring dengan sistematika tertentu agar dapat mudah dipahami. Hasilnya akan dianalisis dan dipelajari guna menghasilkan pengetahuan-pengetahuan baru yang nantinya dapat digunakan sebagai dasar pendukung keputusan yang akan diambil selanjutnya.

Perusahaan yang bergerak di bidang pendidikan atau lebih sering disebut instansi pendidikan, juga memiliki proses bisnis yang sebagian besar mirip dengan perusahaan atau industri jasa[6]. Dengan kemiripan proses bisnis tersebut, tentu terdapat kompleksitas pengelolaan sumber daya yang tidak dapat dipandang sebelah mata. Proses bisnis yang dijalankan oleh instansi pendidikan memiliki beberapa jenjang sesuai dengan yang telah ditetapkan oleh pemerintah. Institusi pendidikan tinggi atau perguruan tinggi adalah instansi pendidikan yang melaksanakan proses bisnis pada jenjang tertinggi. Menurut pemerintah, definisi dari institusi pendidikan tinggi adalah satuan pendidikan yang menyelenggarakan pendidikan tinggi dimana pendidikan tinggi adalah jenjang pendidikan setelah pendidikan menengah yang mencakup program diploma, program sarjana, program magister, program doktor, dan program profesi, serta program spesialis [7]. Selain itu, setiap institusi pendidikan tinggi tentunya memiliki beberapa program studi. Program studi sendiri dapat diartikan sebagai kesatuan kegiatan pendidikan dan pembelajaran yang memiliki kurikulum dan metode pembelajaran tertentu dalam satu jenis pendidikan akademik, pendidikan profesi, dan pendidikan vokasi [7].

Peran pendidikan tinggi tidak hanya untuk mendidik mahasiswa untuk pekerjaan di masa depan tetapi juga untuk melatih karyawan masa depan untuk melakukan tugas-tugas kerja, dan idealnya, untuk menghasilkan inovasi[8]. Sistem pendidikan tinggi yang kuat penting dalam membentuk sumber daya manusia yang profesional untuk segala lini profesi seperti layanan publik, mendorong inovasi dan mengembangkan solusi yang dihasilkan secara lokal untuk tantangan pembangunan[9]. Pengelolaan yang dilakukan institusi pendidikan tinggi tidak hanya bertujuan untuk terciptanya proses kegiatan akademik yang optimal tetapi juga bertujuan untuk membangun institusi pendidikan tinggi dan program studi itu sendiri menjadi sebuah instansi pendidikan yang lebih baik dan berkelanjutan [10], salah satunya dengan akreditasi yang merupakan sarana dominan untuk menjamin dan meningkatkan kualitas perguruan tinggi dan universitas di banyak negara di seluruh dunia[11]. Walaupun kedua macam pengelolaan tersebut memiliki tujuan dan sudut pandang yang berbeda, namun keduanya memiliki visi yang yaitu kualitas pendidikan yang optimal. Beranjak dari hal tersebut, dirancang suatu sistem yang dapat melakukan proses monitoring dengan menggunakan standar yang telah ditetapkan oleh BAN-PT (Badan Akreditasi Nasional Perguruan Tinggi) selaku badan penilai akreditasi. 


\section{Tinjauan Pustaka}

Penelitian yang dilakukan oleh Rui Pedro Marques, Henrique Santos, dan Carlos [2] mengatakan bahwa dengan mengontrol dan mengaudit transaksi secara real time dapat menghasilkan pengetahuan tentang seberapa besar kehandalan dari transaksi yang dilakukan. Hal ini menggambarkan pentingnya proses monitoring dalam untuk menvalidasi serta mengontrol suatu transaksi. Mereka juga menyebutkan dalam penelitiannya bahwa suatu transaksi adalah bagian terkecil dari sebuah proses bisnis perusahaan. Setiap bagian ini akan menjadi hal yang krusial dalam membangun suatu perusahaan. Pernyataan ini secara tidak langsung ikut menekankan pentingnya sebuah proses monitoring sebagai bagian dari kontrol transaksi.

Pada penelitian yang dilakukan oleh Zubair Ahmed Memon, Muhd. Zaimi Abd. Majid, dan Mushairry Mustaffar [12], proses monitoring dan kontrol merupakan salah satu tugas terpenting yang harus dilakukan dalam memanajemen suatu projek. Semua anggota tim yang menjalankan projek tersebut harus mengetahui setiap pencapaian yang terjadi secara tepat waktu dan akurat. Setiap pencapaian yang terjadi nantinya akan dibandingkan dengan rencana awal yang telah dibuat sebelumnya. Tujuannya adalah agar projek yang dijalankan dapat semirip mungkin bahkan sesuai dengan rencana awal yang ditetapkan.

Monitoring tidaklah lengkap tanpa adanya evaluasi, karena monitoring dan evaluasi memiliki peran yang sama-sama penting dan melengkapi satu sama lain dalam mengontrol transaksi yang ada. Pada sumber yang ditulis oleh [4] dikatakan bahwa evaluasi dalam pemerintahan dapat meningkatkan transparansi, menguatkan akuntabilitas, serta meningkatkan performa. Tiga kata kunci yang penting dalam pernyataan ini adalah transparansi, akuntabilitas, dan performa. Walaupun dalam hal ini lingkupnya adalah pemerintahan, namun tidak menutup kemungkinan kelebihan-kelebihan ini dapat memberi dampak positif di bidang lain.

Transparansi berarti dengan melakukan evaluasi, akan dapat terlihat rincian transaksi sampai ke bagian yang terkecil seperti mengapa transaksi dilakukan serta keterangan lain yang berhubungan dengan transaksi tersebut. Dalam proses evaluasi akan dilakukan perincian atau pemecahan suatu informasi yang didapat menjadi bagian-bagian yang lebih kecil dengan struktur tertentu agar informasi tersebut dapat diserap, dipahami, dan dipelajari dengan lebih baik. Dengan begitu, penggalian terhadap detil-detil informasi tersebut dapat tergali lebih dalam dan dapat menghasilkan pengetahuan baru bagi pelaku bisnis.

Akuntabilitas dalam sebuah transaksi adalah hal yang secara eksak dilakukan sehingga dapat dihitung performanya dari berbagai sudut pandang. Semakin rinci dan detil informasi yang ada akan membuat proses perhitungan lebih akurat. Di lain sisi evaluasi dapat memberikan tingkat kerincian informasi yang lebih banyak berdasarkan transaksi yang ada. Kedua hal inilah yang menjadi alasan mengapa evaluasi dapat menguatkan akuntabilitas.

Peningkatan performa yang diakibatkan dari adanya proses evaluasi lebih kepada kemudahankemudahan dalam menjalankan proses bisnis. Dengan dilakukannya evaluasi akan menghasilkan pengetahuan baru yang dapat mendukung keputusan untuk menentukan langkah mana yang paling optimal demi kemajuan proses bisnis. Dengan adanya evaluasi, pelaku bisnis dapat melakukan proses bisnisnya dengan lebih mudah, akurat, dan optimal.

Penelitian yang dilakukan oleh Endi Putro [13] dan Atin Triwahyuni [14] menggunakan sistem informasi sebagai tempat di mana semua yang berhubungan dengan borang akreditasi dapat terkumpul menjadi satu. Hal ini bertujuan untuk memudahkan perguruan tinggi dalam mengolah informasi yang ada. Secara tidak langsung, hal ini juga akan memudahkan dilakukannya proses monitoring dan evaluasi. Hal ini mirip dengan penelitian yang dilakukan di program studi Sistem Informasi Institut Teknologi Sepuluh Nopember [15]. Sistem informasi dokumentasi borang akreditasi memudahkan perguruan tinggi dalam mengetahui paparan dan gambaran tentang kondisi institusi sampai saat ini.

Dengan kata lain, sistem informasi adalah salah satu alat yang dapat digunakan untuk melakukan proses monitoring dan evaluasi. Dalam hal ini, sistem informasi berperan dalam membantu sistem secara keseluruhan dari segi teknisnya. Pada penelitian yang dilakukan oleh Faulinda Ely Nastiti dan 
Susanto [16] monitoring perlu dilakukan untuk meningkatkan jumlah lulusan yang ingin dicapai oleh perguruan tinggi. Hal ini berarti proses monitoring dan evaluasi sebenarnya tidak hanya dilakukan pada tahap proses di proses bisnisnya saja namun juga dapat dilakukan pada hasil dari proses bisnisnya. Tujuannya untuk mengecek dan meninjau kembali proses bisnis yang dilakukan apakah sudah optimal atau belum.

\section{Metodologi Penelitian}

\subsection{Tahapan Penelitian}

Tahapan penelitian yang dilakukan penulis dalam penelitian ini adalah sebagai berikut:

1. Penulis melakukan wawancara dengan pihak program studi untuk memahami proses bisnis yang berjalan dan mengumpulkan detil informasi terhadap masalah yang dihadapi.

2. Penulis melakukan studi literatur mengenai teori-teori yang terkait beserta penelitianpenelitian yang sudah dilakukan sebelumnya yang berhubungan dengan masalah yang dihadapi.

3. Penulis melakukan pengumpulan informasi tentang standar penilaian pada borang akreditasi dengan meminta lembar penilaian beserta rumus-rumus penilaian yang diberikan oleh BANPT pada pihak program studi. Standar ini nantinya akan digunakan sebagai acuan atau dasar dari solusi yang akan diterapkan.

4. Dari informasi yang sudah dikumpulkan sebelumnya, penulis melakukan analisis untuk menentukan mana informasi yang dibutuhkan dan mana informasi yang tidak dibutuhkan. Setelah itu, penulis melakukan pemodelan dengan arsitektur dari sistem yang akan dibangun berdasarkan bagaimana proses bisnis yang ada dapat berjalan. Dari hal yang sudah dilakukan, penulis melakukan pembangunan sistem berdasarkan arsitektur yang telah dibuat sebelumnya. Pembangunan ini merupakan bentuk kongkrit nyata dari solusi yang telah ditentukan terhadap permasalahan yang ada.

\subsection{Alat dan Bahan}

Alat dan bahan yang digunakan penulis dalam melakukan penelitian ini adalah sebagai berikut:

1. Perangkat lunak pengolah kata sederhana seperti Microsoft Notepad, Notepad++, dan Sublime Text. Perangkat lunak ini digunakan penulis sebagai alat dalam melakukan penulisan kode program sistem. Dalam hal ini, sistem dibangun menggunakan bahasa pemrograman PHP.

2. Peramban web (Web Browser), yaitu perangkat lunak yang digunakan untuk menjelajah internet seperti Microsoft Internet Explorer, Mozilla Firefox, Google Chrome, dan Opera. Perangkat lunak ini digunakan sebagai media sistem berjalan dan diakses oleh pengguna. Penulis menggunakan peramban web yang sudah mendukung bahasa pemrograman HTML5 dan JavaScript.

3. Apache Server, perangkat lunak yang digunakan untuk menyediakan akses pengguna ke sistem melalui protokol HTTP.

4. MySQL, perangkat lunak yang digunakan untuk menyimpan dan memanajemen basis data sistem.

5. Microsoft Windows, sistem operasi yang digunakan untuk menjalankan keseluruhan sistem beserta perangkat lunak lain yang menopang sistem. Sistem dapat berjalan di Microsoft Windows XP atau versi Windows yang lebih baru.

6. Microsoft Excel, perangkat lunak ini digunakan sebagai alat untuk membuka dan membaca laporan yang dihasilkan oleh sistem. Laporan yang dihasilkan oleh sistem dapat dibuka dan dibaca di Microsoft Excel 2007 atau versi Excel yang lebih baru. 


\section{Hasil dan Pembahasan}

\subsection{Analisis Proses Bisnis}

Monitoring dan evaluasi sudah seharusnya diterapkan di berbagai bidang bisnis tak terkecuali bidang pendidikan. Alasannya adalah terdapat banyak sekali proses dan transaksi yang terjadi di sebuah institusi pendidikan tinggi sebagai salah satu perusahaan yang bergerak di bidang pendidikan. Di lain sisi, pendidikan adalah hal yang krusial karena mendidik berarti menanamkan nilai-nilai kehidupan sebagai bekal bagi peserta didik untuk diaplikasikan kepada sesama dan bangsanya. Dari situlah proses pendidikan ini harus dijaga kualitasnya, serta harus memiliki suatu standar yang tinggi beserta indikator-indikator yang jelas. Mulai dari institusi pendidikan tinggi, dapat diperdalam lagi ke tingkat program studinya. Pada tingkat ini, setiap peserta didik diajarkan keahlian khusus agar kelak mereka memiliki sebuah role dalam masyarakat, berbekal dari keterampilan dan pengetahuan yang dipelajari saat kuliah. Tentu pada tingkat ini juga memiliki standar yang sama dalam hal kualitasnya. Dari semua hal tersebut munculah suatu kesimpulan yaitu bahwa proses bisnis di bidang pendidikan merupakan suatu proses bisnis yang kompleks dan perlu manajemen yang baik pula.

Dalam mengukur kualitas sebuah program studi, pemerintah mengukurnya dengan menggunakan akreditasi. Akreditasi sebuah program studi dilakukan oleh Badan Akreditasi Nasional Perguruan Tinggi (BAN-PT) dengan tujuan sesuai pasal 60 ayat 1 Undang-Undang Republik Indonesia Nomor 20 Tahun 2003 yaitu "Akreditasi dilakukan untuk menentukan kelayakan program dan satuan pendidikan pada jalur pendidikan formal dan nonformal setiap jenjang dan jenis pendidikan"[17]. Akreditasi sebuah program studi dibagi dan dikelompokkan ke dalam tujuh buah standar. Ketujuh standar tersebut nantinya berisi indikator-indikator penilaian yang digunakan oleh BAN-PT untuk melakukan proses akreditasi terhadap sebuah program studi. Indikator-indikator penilaian tersebut nantinya akan tertera dalam sebuah formulir yang disebut borang akreditasi dalam bentuk butir yang berjumlah tujuh buah sesuai dengan jumlah standar yang ada, serta setiap butirnya akan terbagi menjadi beberapa sub butir yang totalnya sejumlah 100 buah. Formulir ini nantinya akan diisi oleh program studi dan akan diverifikasi oleh BAN-PT. Secara umum, penilaian borang akreditasi terbagi ke dalam 5 nilai yaitu sangat baik (4), baik (3), cukup (2), kurang (1), dan sangat kurang (0). Untuk beberapa sub butir, nilai ini bersifat bulat. Sedangkan untuk beberapa sub butir yang tidak dapat diukur secara eksak, kelima nilai ini akan membentuk sebuah batasan nilai. Sehingga dalam melakukan penilaian beberapa sub butir tersebut, pengisi borang akreditasi dapat menuliskan bilangan desimal dengan ketelitian dua angka dibelakang koma sebagai bentuk nilai yang paling cocok dan mendekati keadaan aslinya.

Proses akreditasi juga merupakan suatu proses bisnis di bidang pendidikan. Penulis mengangkat proses bisnis ini dikarenakan dari proses bisnis ini, dapat dilihat dengan jelas peran program studi yaitu mengisi borang akreditasi sebagai instrumen akreditasi. Informasi yang mengalir sebagai bahan pengisian borang ini tidaklah sedikit. Informasi tersebut memiliki jumlah yang banyak dan juga memiliki kompleksitas yang tinggi karena saling berkaitan satu sama lain serta beberapa informasi tidak dapat berdiri sendiri.Untuk itu perlu dilakukan proses monitoring untuk menjaga validitas setiap informasi yang ada. Selain itu, informasi-informasi ini secara tidak langsung menjadi gambaran keadaan suatu program studi. Untuk mendapatkan gambaran yang lebih jelas tentang keadaan tersebut, maka perlu dilakukan proses evaluasi terhadap informasi yang ada.

\subsection{Pembahasan Penelitian}

Dalam melakukan penelitian ini, penulis menggunakan standar yang tertera pada borang akreditasi sebagai alat ukur kualitas dari sebuah program studi. Pemilihan alat ukur ini memiliki beberapa alasan. Alasan pertama, pihak program studi dan BAN-PT selaku pembuat borang akreditasi memiliki tujuan yang sama yaitu ingin meningkatkan kualitas dan kredibilitas dari program studi itu sendiri walaupun dari cara pandang yang berbeda. Alasan lainnya adalah standar yang terdapat pada borang akreditasi telah teruji dan sudah digunakan oleh BAN-PT untuk mengukur kualitas program studi yang ada.

Wijaya (Sistem Monitoring dan Evaluasi Pengelolaan Program Studi di Institusi Pendidikan Tinggi) 
Berangkat dari hal tersebut, maka dibuatlah suatu sistem yang dapat membantu institusi pendidikan tinggi dalam mengukur kualitas program studinya dengan arsitektur sebagai berikut.

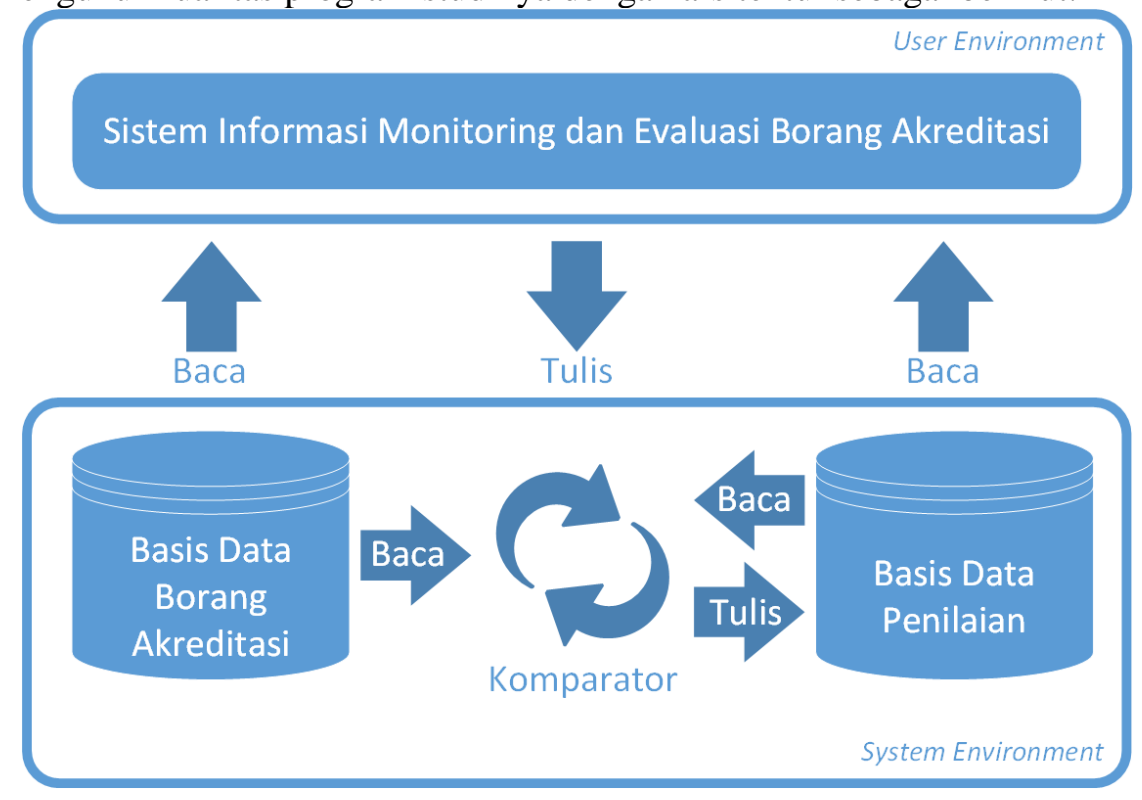

Gambar 1. Arsitektur Sistem Monitoring dan Evaluasi Borang Akreditasi.

Pada gambar 1 arsitektur sistem dibagi menjadi dua bagian yaitu batasan pengguna (User Environment) dan batasan sistem (System Environment). Batasan pengguna berisi tentang bagaimana calon pengguna sistem berinteraksi dengan sistem secara keseluruhan. Sedangkan batasan sistem berisi mekanisme kerja sistem. Pada arsitektur ini juga terdapat dua buah tempat penyimpanan atau basis data yaitu Basis Data Borang Akreditasi dan Basis Data Penilaian.Basis Data Borang Akreditasi berisi informasi-informasi terkait borang akreditasi seperti data mahasiswa, data dosen, data penelitian dan pengabdian, serta beberapa data lainnya. Sedangkan basis data Basis Data Penilaian berisi hasil dari proses evaluasi dari Basis Data Borang Akreditasi serta berisi aturan-aturan yang digunakan sebagai alat pengontrol mekanisme kerja sistem. Diantara kedua basis data tersebut terdapat Komparator yang bertugas untuk menerjemahkan informasi dari Basis Data Borang Akreditasi yang bersifat informasi mentah menjadi pengetahuan baru berupa nilai-nilai yang dapar diukur dan disimpan ke Basis Data Penilaian. Dalam melakukan proses perhitungan, Komparator menggunakan aturan-aturan yang berasal dari Basis Data Penilaian sebagai alat ukur atau pembanding.

Beralih ke sistem informasi yang terdapat pada batasan pengguna, dengan sistem ini calon pengguna dapat melihat hasil dari proses komparasi tadi dalam bentuk nilai-nilai beserta keterangan atau nilai yang didapat. Pengguna juga dapat melakukan perbandingan suatu nilai dengan nilai yang didapat pada proses evaluasi sebelumnya. Karena beberapa nilai tidak dapat dikalkulasi oleh sistem dengan alasan nilai tersebut tidak dapat diukur dan bersifat subjektif, maka sistem juga dapat menerima masukkan nilai dari pengguna. Masukkan tersebut tetap akan melewati Komparator untuk diterjemahkan dan dievaluasi hasilnya. Sedangkan untuk mengontrol masukkan pengguna agar sesuai dengan batasan yang ditentukan, sistem akan mengambil informasi terkait dari Basis Data Penilaian. Informasi-informasi ini berupa detil nilai yang akan dimasukkan dan aturan-aturan agar nilai yang diinputkan tidak keluar dari batasan. Sistem juga dapat membantu pengguna untuk melihat asal atau data mentah dari suatu nilai yang dihasilkan untuk memastikan validitas nilainya. Untuk itu, sistem juga dapat menampilkan informasi-informasi tersebut dari Basis Data Borang Akreditasi.

Untuk mendukung arsitektur yang dibuat agar dapat berjalan dengan optimal, perlu disesuaikan pula skema basis datanya. Dalam hal ini, pembuatan skema basis data yang ada disesuaikan dengan kebutuhan sistem. Untuk itu, dalam perancangan skemanya menggunakan struktur dari borang akreditasi sebagai dasarnya. Dalam arsitektur yang dibuat terdapat dua buah basis data, Basis Data 
Borang Akreditasi dan Basis Data Penilaian. Basis Data Borang Akreditasi bersifat read only, artinya sistem tidak melakukan penulisan ke dalam basis data ini. Hal ini dikarenakan basis data tersebut hanya bersifat acuan yang digunakan oleh sistem untuk memfasilitasi data yang akan digunakan. Maka dari itu, sistem yang akan menyesuaikan skema dari Basis Data Borang Akreditasi.

Sedangkan untuk Basis Data Penilaian bekerja sebagai basis data utama sistem. Basis data ini juga digunakan sebagai tempat penyimpanan beberapa konfigurasi dari sistem secara keseluruhan. Jadi dalam basis data ini terjadi operasi baca dan tulis baik untuk menyimpan hasil komparasi maupun untuk membaca aturan-aturan yang berhubungan dengan mekanisme kerja sistem.Untuk skema dari basis data ini dapat dilihat pada gambar 2 .

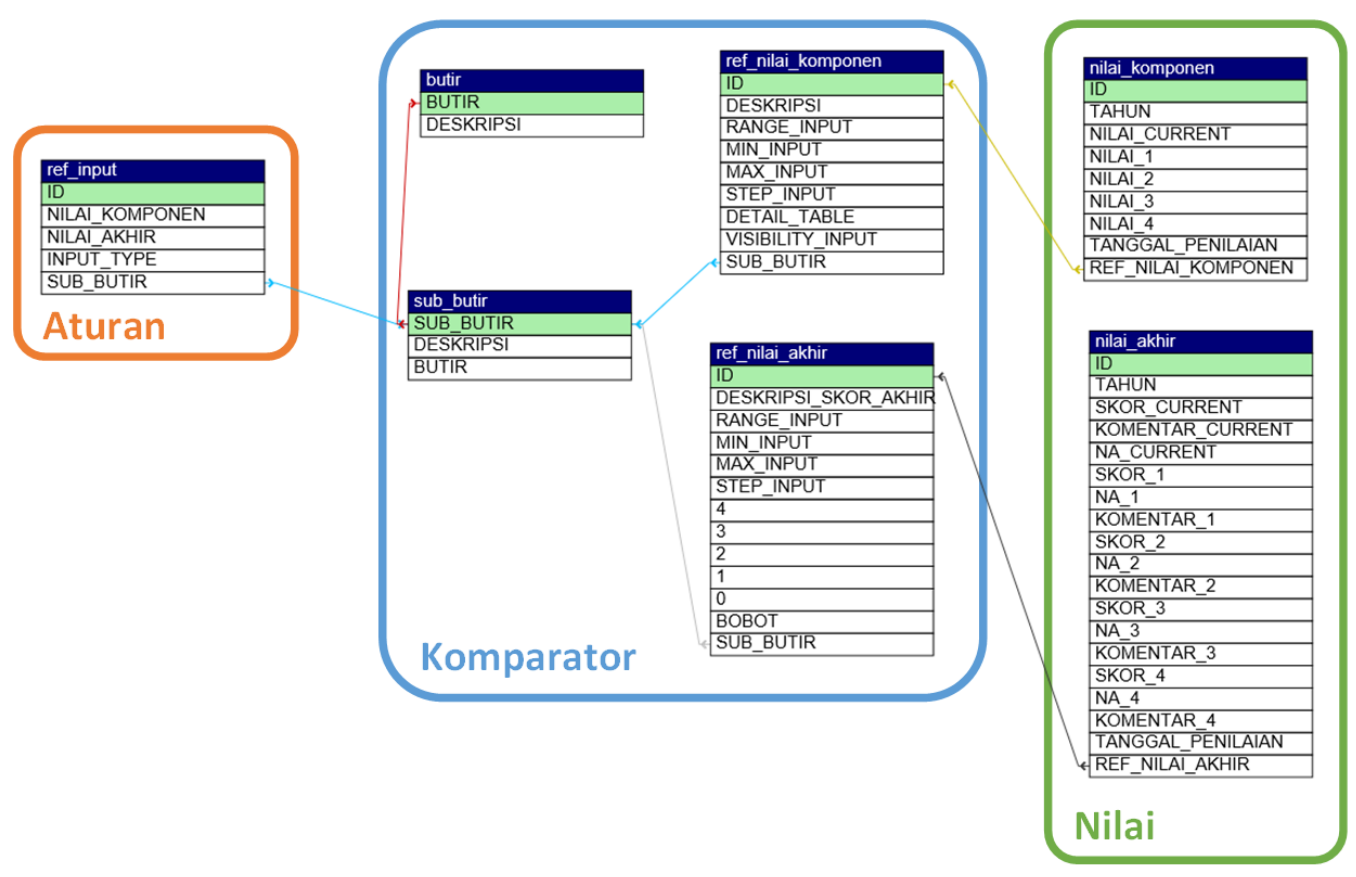

Gambar 2. Skema Basis Data Penilaian.

Pada gambar 2, yaitu tentang skema dari basis data Penilaian, basis data ini dibagi menjadi tiga buah bagian. Bagian pertama adalah bagian Aturan. Bagian ini berisi aturan-aturan yang berhubungan dengan mekanisme kerja sistem. Tujuannya adalah untuk mengontrol masukkan dari pengguna sistem agar dapat sesuai dengan keinginan sistem. Bagian kedua adalah Komparator, bagian ini berisi informasi mengenai borang akreditasi dan aturan-aturan yang digunakan untuk melakukan pengukuran informasi yang ada menjadi nilai yang dapat diukur dan dievaluasi. Pada bagian ini sebenarnya juga memiliki beberapa hal yang berhubungan dengan mekanisme kerja sistem. Jadi kedua bagian ini sebenarnya memiliki beberapa kesamaan, hanya saja pada bagian pertama lebih cenderung ke sistem sebagai sebuah alat untuk melakukan penilaian. Sedangkan bagian kedua lebih cenderung ke aturan penilaiannya. Untuk bagian ketiga yaitu Nilai, bagian inilah yang berfungsi untuk menyimpan hasil kalkulasi yang ada. Jadi hasil dari Komparasi yang dilakukan oleh Komparator akan disimpan di bagian ini. Nantinya pada bagian ini, sistem akan membaca hasilnya dan menampilkannya ke pengguna dengan struktur yang mudah dipahami dan dipelajari oleh pengguna.

Dalam menganalisis dan mengimplementasikan Monitoring dan Evaluasi (M\&E) ke dalam proses bisnisnya, penulis menggunakan sebuah bentuk optimisasi proses bisnis yang disebut Business Process Management (BPM). BPM merupakan suatu pendekatan terstruktur untuk menganalisa, mengoptimalkan, mengontrol, dan memanajemen suatu proses bisnis dengan tujuan untuk meningkatkan kualitas produk dan layanan dari proses bisnis tersebut [18]. Pendekatan yang dilakukan pada proses BPM menggunakan teknik, metode, dan alat yang berbeda-beda untuk disesuaikan dengan proses bisnis yang akan didekati. Tujuannya untuk menghasilkan pendekatan yang lebih personal 
terhadap proses bisnis yang ada. Bentuk siklus dari BPM menurut Stefan R. Koster dapat dilihat pada gambar 3.

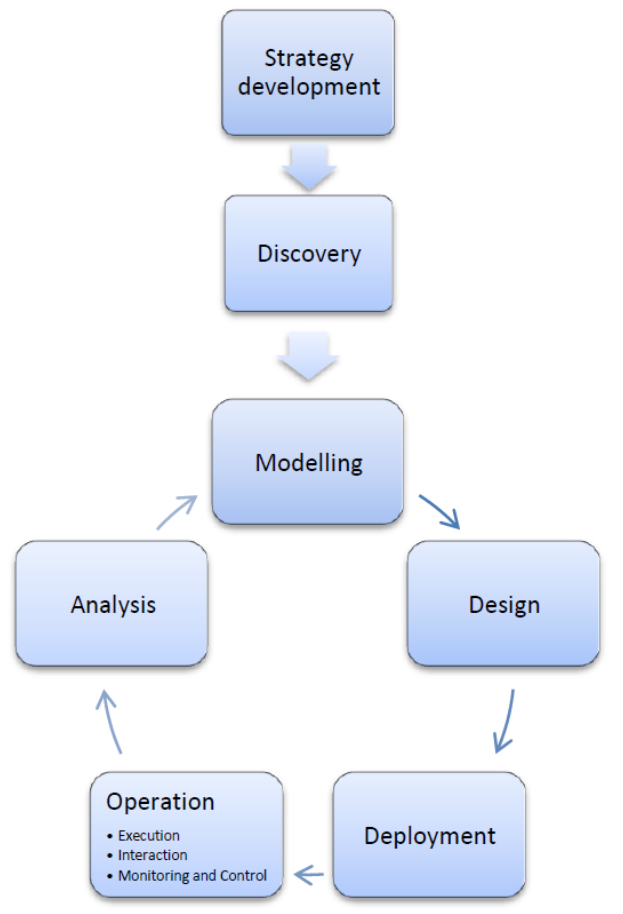

Gambar 3. Siklus Business Process Management[18]

Gambar 3 menunjukkan siklus Business Process Management (BPM). Siklus ini diawali dengan fase Strategy Development, yaitu fase persiapan untuk menentukan apa saja tujuan dan sasaran yang ingin dicapai. Selanjutnya dilanjutkan oleh fase Discovery yang berisi pengumpulan informasi terkait proses bisnis yang ada lalu fase Modelling untuk memodelkan proses bisnisnya. Setelah itu adalah fase Design, di mana fase ini mengubah model yang sudah dibentuk sebelumnya menjadi sebuah bentuk yang dapat diterapkan secara konkret dalam proses bisnis. Bentuk desain tersebut kemudian diterapkan ke perusahaan pada fase Deployment dan dieksekusi, dimonitoring, dan dikontrol pada fase Operation. Hasil dari fase Operation selanjutnya dievaluasi dan dianalisis pada fase Analysis untuk menentukan keputusan selanjutnya maupun model selanjutnya yang lebih optimal.

BPM berperan dalam membantu pelaku bisnis untuk beradaptasi dan menyesuaikan proses bisnisnya agar dapat lebih fleksibel menghadapi perubahan zaman yang tidak stabil.Cara yang dilakukan BPM untuk mengatasinya adalah dengan memfasilitasi pelaku bisnis seperti mendefinisikan, memodelkan, mengontrol dan memonitoring, serta mengoptimisasi proses bisnis yang ada.Perlu dicermati pada gambar 3. tentang siklus BPM, yaitu pada fase Operation dan fase Anaysis terjadi proses monitoring dan evaluasi yang mana proses monitoring dilakukan pada fase Operation sedangkan proses evaluasi dilakukan pada fase Anaysis. Dalam melakukan monitoring, BPM membagi bentuk monitoring ke dalam dua sudut pandang yang berbeda, yaitu dari sisi teknis dan dari sisi bisnis. Sisi teknis akan membahas mengenai monitoring yang dilakukan agar sistem dapat berjalan dengan normal. Sedangkan dari sisi bisnis, sisi ini membahas tentang informasi-informasi yang mengalir di proses bisnisnya agar dapat selalu valid. Untuk melakukan monitoring dari sisi ini, dapat dilakukan secara aktif yaitu monitoring dilakukan secara otomatis, maupun secara pasif yaitu perlu aksi dari pengguna untuk melakukan monitoring. Untuk lebih jelasnya dapat dilihat pada gambar 4.4. tentang tahapan monitoring menurut Stefan R. Koster. 


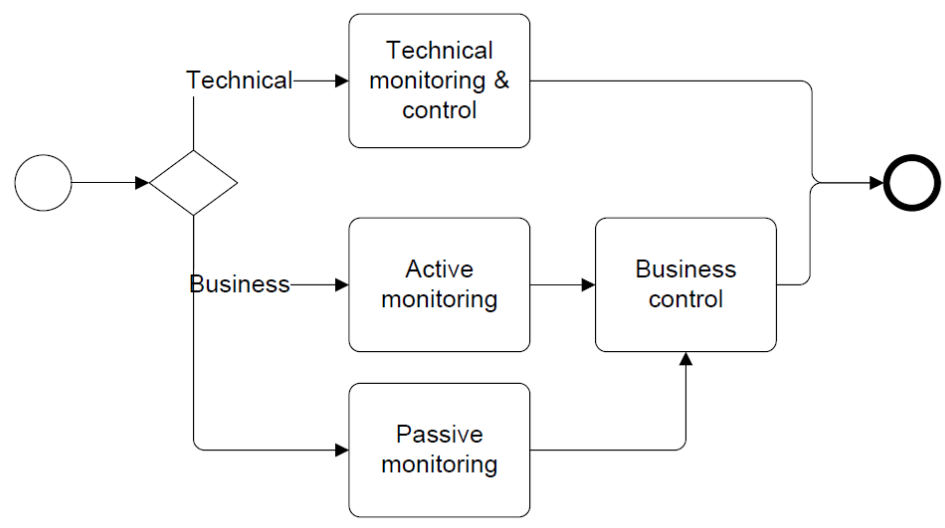

Gambar 4. Tahapan Monitoring[18]

Dalam sistem yang dibangun, penulis melakukan monitoring dari sisi teknis maupun bisnis. Pada sisi teknis, untuk menjamin sistem dapat menampilkan semua nilai, baik yang sudah terjadi penilaian maupun belum, penulis menggunakan data kosong untuk setiap nilai yang ada. Hal ini akan membantu sistem dalam menentukan tindakan terhadap nilai-nilai yang belum terproses secara lengkap. Sedangkan dari sisi bisnis, sistem melakukan monitoring secara aktif setiap 12 jam sekali. Hal ini bertujuan agar pengguna selalu mendapatkan penilaian yang terbaru tanpa membebani sistem secara signifikan. Sedangkan untuk monitoring yang bersifat pasif, sistem akan melakukan monitoring untuk beberapa nilai tertentu saat nilai tersebut dimasukkan oleh pengguna secara manual ke sistem. Saat nilai-nilai tersebut dimasukkan oleh pengguna, sistem akan memonitor masukkan pengguna agar dapat sesuai dengan batasan yang ditentukan.

Dalam melakukan evaluasi, terdapat tiga teknik yaitu verifikasi, simulasi, dan kuantifikasi[18]. Verifikasi digunakan untuk mengecek kebenaran aliran informasi terhadap proses bisnis yang ada. Sedangkan simulasi digunakan untuk mensimulasikan proses bisnis dengan tujuan mendapatkan gambaran yang jelas akan proses bisnisnya. Berbeda dengan kuantifikasi, teknik ini lebih berfokus terhadap perhitungan untuk mencari hasil analisis yang diinginkan. Pada sistem yang dibangun, detil informasi yang menjadi dasar dihasilkannya suatu nilai dapat dilihat oleh pengguna. Hal ini bertujuan agar pengguna dapat melihat aliran informasi yang ada.hal ini membantu pengguna untuk menganalisis dengan melakukan verifikasi kebenaran hasil terhadap informasi yang dikalkulasi. Sedangkan proses kalkulasi yang dilakukan oleh komparator didasarkan pada kuantifikasi dengan standar borang akreditasi. Untuk simulasi, sistem ini tidak dapat mensimulasikan terhadap kasus tertentu karena sistem ini lebih berfokus pada monitoring borang akreditasi secara langsung dan memfasilitasi untuk dilakukan proses evaluasi awal. Namun histori penilaian yang disimpan di sistem dapat digunakan pengguna sebagai salah satu acuan dalam mendapat gambaran terhadap kasus tertentu yang terjadi di program studi.Sedangkan dalam melakukan pembangunan arsitektur sistem beserta pembangunan mekanisme kerja sistemnya, penulis menggunakan model siklus Result Based Management (RBM) untuk dapat melihat keterkaitan proses Monitoring dan Evaluasi (M\&E) secara langsung terhadap stakeholder yang ada. Result Based Management (RBM) adalah strategi manajemen agar aktor atau stakeholder yang ada dapat memberikan kontribusi secara langsung maupun tidak langsung terhadap hasil yang diinginkan[19]. Model siklus Result Based Management (RBM) dapat dilihat pada gambar 5. 


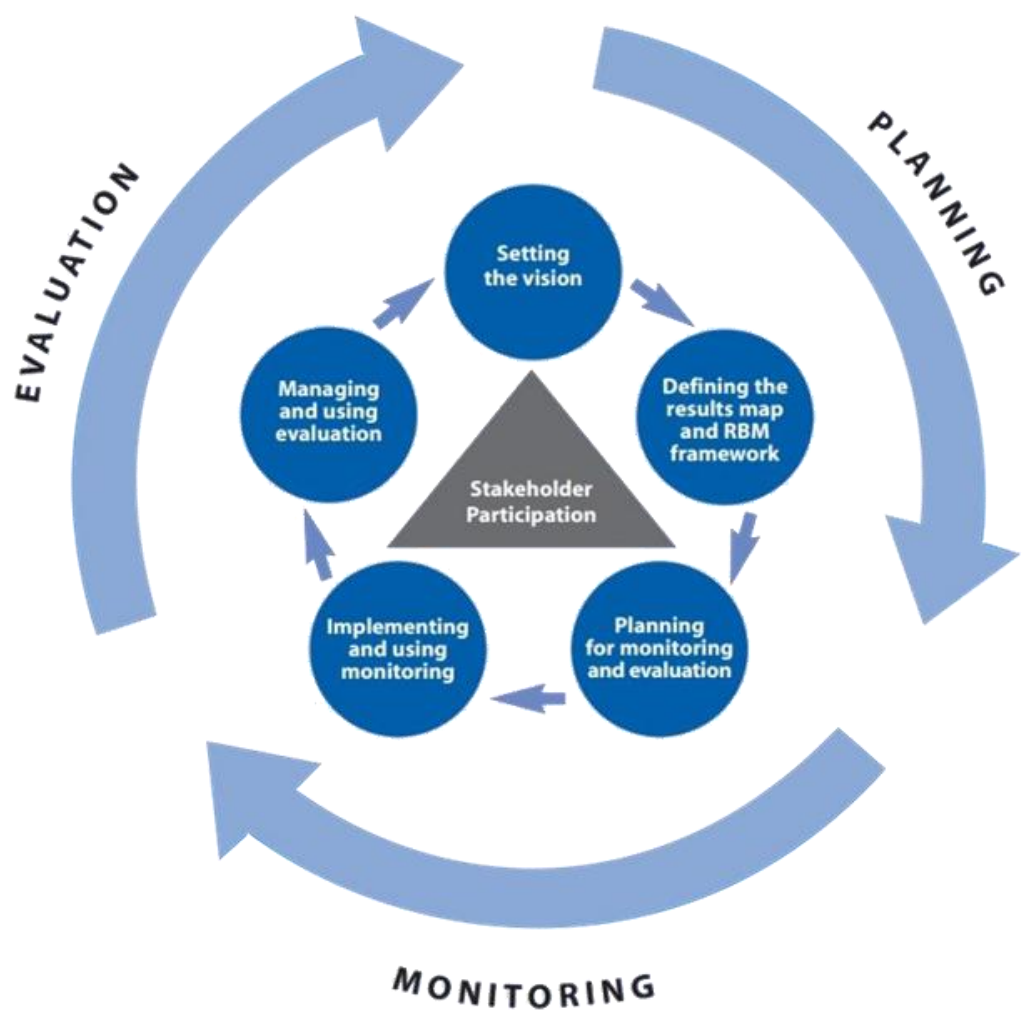

Gambar 5. Siklus Result Based Management[19]

Pada gambar 5, yaitu pada fase Planning, terdapat pendefinisian hal-hal yang ingin dicapai seperti mendefinisikan pandangan bersama tentang projek yang ada serta mendefinisikan hasil yang diinginkan. Selain itu didefinisikan juga kerangka RBM agar relasi antara setiap stakeholder dengan proses yang ada dapat terlihat jelas. Setelah itu dilakukan perencanaan monitoring dan evaluasinya untuk memantau kontribusi stakeholder yang ada. Perencanaan tersebut akan dijadikan dasar dilakukannya proses monitoring dan evaluasi pada dua fase berikutnya yaitu fase Monitoring dan fase Evaluation. Kedua fase ini berisi implementasi dan manajemen aksi yang dilakukan stakeholder beserta proses monitoring dan evaluasi agar setiap aksi tersebut dapat sesuai dengan hasil yang telah direncanakan sebelumnya pada fase Planning. Pada tahap terakhir, hasil dari evaluasi akan menjadi dasar untuk menentukan pandangan dan tujuan yang akan didefinisikan selanjutnya.

Untuk menjalankan sebuah proses monitoring dan evaluasi tentunya dibutuhkan perencanaan terlebih dahulu. Hal ini penting karena proses monitoring tidak serta merta hanya mengamati perkembangan suatu tugas dengan rutin saja lalu dicatat hasilnya.Pada tahap ini, sistem yang dibuat melakukan proses pencatatan dan proses kalkulasi menggunakan komparator sebanyak empat kali dalam satu tahun. Empat buah penilaian ini nantinya dibagi menjadi empat kuarter sesuai dengan permintaan program studi. Untuk setiap kuarternya, pencatatan akan terus diperbaharui ulang setiap satu jam sekali pada hari terakhir kuarter tersebut. Tujuannya adalah agar pengguna sistem selalu mendapat pencatatan terbaru untuk setiap perubahan informasi yang terjadi. Di lain sisi, dengan rentang waktu pencatatan sebesar satu jam akan mengurangi beban sistem saat bekerja tanpa mengorbankan validitas informasi yang ada secara signifikan.

Perencanaan tentunya juga dilakukan untuk proses evaluasi agar dapat memperoleh hasil yang optimal. Dalam mengevaluasi informasi yang ada, perlu ditentukan metode pengolahan informasinya. Tujuannya agar informasi tersebut dapat terpecah secara lengkap dan detil dalam suatu struktur yang mudah dipahami dan mudah dianalisis. Untuk tahap ini, dilakukan pengolahan informasi berdasarkan kriteria penilaian yang terdapat pada borang akreditasi. Dengan begitu, struktur dari penilaian akan terbagi dan dikelompokkan menjadi beberapa butir dan sub butirnya. Setiap butir dan subbutir yang

Wijaya (Sistem Monitoring dan Evaluasi Pengelolaan Program Studi di Institusi Pendidikan Tinggi) 
ada, akan berisi informasi yang berkaitan dengan peran butir dan subbutir tersebut dalam kriteria penilaian. Selain itu juga terdapat informasi lain seperti aturan penilaian dengan rentang nilai nol sampai empat. Nilai yang ada nantinya akan ditampilkan secara urut dan terstruktur dalam bentuk tabel dan grafik. Tujuannya adalah untuk memberikan gambaran yang jelas serta memudahkan program studi dalam membandingkan nilai yang ada.

Tampilan tersebut nantinya masih akan ditampilkan dalam tiga bentuk. Bentuk pertama yaitu menampilkan seluruh nilai akhir sub butir, tampilan ini berisi kumpulan nilai akhir dari setiap sub butir yang ada. Tujuannya untuk memudahkan program studi dalam melihat penilaian secara keseluruhan. Sedangkan tampilan kedua adalah menampilkan nilai akhir dari sub butir tertentu. Tampilan ini mirip seperti tampilan sebelumnya, hanya saja tampilan ini lebih mengacu ke detil nilai akhir sebuah sub butir sehingga terdapat informasi-informasi tambahan yang berkaitan dengan nilai akhir butir tersebut. Tampilan ketiga adalah menampilkan nilai komponen dari suatu sub butir. Tampilan ini berisi informasi-informasi yang mendukung dihasilkannya nilai akhir dari suatu sub butir. Ketiga macam tampilan ini bertujuan untuk melihat hasil komparasi sesuai dengan kebutuhan program studi.Dalam membandingkan nilai yang ada, diperlukan minimal satu kali penilaian dalam satu tahun. Penilaian tersebut akan menjadi pembanding dengan hasil dari penilaian yang lain dalam tahun yang sama. Hal ini dikarenakan pihak program studi ingin melihat keadaan program studinya dalam satu tahun. Dari situ, pihak program studi akan lebih mudah dalam melakukan proses evaluasi akan keadaan program studinya dari tahun ke tahun.

\section{Kesimpulan}

Berdasarkan analisis yang dilakukan terhadap proses bisnis yang ada diikuti dengan tahap perancangan menghasilkan sebuah sistem yang dapat melakukan monitoring dan evaluasi terhadap kinerja program studi. Sistem ini nantinya dapat memonitor sumber daya yang terdapat dalam sebuah program studi. Nantinya, sumber daya tersebut akan dikalkulasi dan dibandingkan dengan standar yang telah ditetapkan pada borang akreditasi. Hasil dari perbandingan tersebut adalah suatu nilai yang menjadi tolak ukur kualitas dari sumber daya yang ada. Nilai-nilai tersebut nantinya akan dievaluasi menggunakan dasar dokumen pengisian borang akreditasi dan dibandingkan dengan penilaianpenilaian yang sudah dilakukan sebelumnya. Tujuannya adalah agar dapat membantu pihak program studi mengenai paparan program studi saat ini.

Monitoring dan evaluasi yang diterapkan pada proses bisnis di bidang pendidikan dapat membantu pihak institusi pendidikan untuk lebih memahami pertukaran informasi yang terjadi di proses bisnisnya. Dalam proses bisnis akreditasi, pihak program studi berperan dalam mengisi borang akreditasi. Tentunya dalam melakukan pengisian ini pihak program studi harus mengerti betul tentang segala informasi yang terkait dengan program studi tersebut. Di lain sisi bagi pihak program sudi, informasi-informasi tersebut tentunya juga berguna sebagai dasar program studi dalam mengambil tindakan terkait proses bisnis yang ada.

\section{Referensi}

[1] D. Budiyanto and D. B. Setyohadi, "Strategic information system plan for the implementation of information technology at Polytechnic 'API' Yogyakarta," in 2017 5th International Conference on Cyber and IT Service Management, CITSM 2017, 2017.

[2] R. P. Marques, H. Santos, and C. Santos, "A solution for real time monitoring and auditing of organizational transactions," Procedia Technol., 2012.

[3] Mudjahidin and N. D. P. Putra, "RANCANG BANGUN SISTEM INFORMASI MONITORING PERKEMBANGAN PROYEK BERBASIS WEB STUDI KASUS DI DINAS BINA MARGA DAN PEMANTUSAN," J. Tek. Ind., 2010.

[4] T. Clark, Quality Assurance: Monitoring and Evaluation to Inform Practice and Leadership. Microsoft Corporation, 2015.

[5] M. Ďrišová, A. Kucharčíková, and Emese Tokarčíková, “Assessment of Higher Education Teaching Outcomes (Quality of Higher Education)," Procedia - Soc. Behav. Sci., vol. 174, pp. 2497-2502, 2015. 
[6] M. D.Uncles, "Directions in higher education: A marketing perspective," Australas. Mark. J., vol. 26, no. 2, pp. 187-193, 2018.

[7] Pemerintah Indonesia, Undang-Undang Republik Indonesia Nomor 12 Tahun 2012 Tentang Pendidikan Tinggi. Pemerintah Indonesia, 2012.

[8] M. Keinänen, J. Ursin, and Kari Nissinen, "How to measure students' innovation competences in higher education: Evaluation of an assessment tool in authentic learning environments," Stud. Educ. Eval., vol. 58, pp. 30-36, 2018.

[9] Tristan McCowan, "Quality of higher education in Kenya: Addressing the conundrum," Int. J. Educ. Dev., vol. 60, pp. 128-137, 2018.

[10] A. M. Aleixo, S. Leal, and U. M. Azeiteiro, "Conceptualization of sustainable higher education institutions, roles, barriers, and challenges for sustainability: An exploratory study in Portugal," J. Clean. Prod., vol. 172, pp. 1664-1673, 2018.

[11] J.S.Eaton, "The Role of Accreditation of Higher Education Institutions," International Encyclopedia of Education (Third Edition). pp. 384-389, 2010.

[12] Z. A. Memon, M. Z. A. Majid, and Mushairry Mustaffar, "A Systematic Approach for Monitoring and Evaluating the Construction Project Progress," J. - Inst. Eng., vol. 67, no. 3, pp. 26-32, 2006.

[13] Endi Putro, "Aplikasi Sistem Penyusunan Borang Akreditasi Program Studi (Buku III-A)," J. Tek. dan Ilmu Komput., vol. 3, no. 9, pp. 98-107.

[14] Atin Triwahyuni, "Pengembangan Sistem Informasi Data Center Sebagai Penyedia Data Penyusunan Borang Akreditasi," Telematika, vol. 11, no. 1, 2014.

[15] M. R. Rafidianto, Sholiq, and Feby Artwodini Muqtadiroh, "Rancang Bangun Perangkat Lunak Sistem Monitoring Tugas Akhir (TA) Untuk Pengembangan Sistem Informasi Terintegrasi Sesuai Kebutuhan Pengisian Borang Akreditasi BAN-PT Pada Jurusan Sistem Informasi ITS," J. Tek. POMITS, vol. 1, no. 1, pp. 1-6, 2013.

[16] F. E. Nastiti and Susanto, "Prototype Aplikasi Layanan Monitoring Bimbingan Skripsi/Tugas Akhir Menggunakan Service Oriented Architecture Framework," J. Duta.Com, vol. 8, no. 1, 2015.

[17] Badan Akreditasi Nasional Perguruan Tinggi, Buku I: Naskah Akademik Akreditasi Program Studi Sarjana. Jakarta: Badan Akreditasi Nasional Perguruan Tinggi, 2008.

[18] S. R. Koster, "An evaluation method for Business Process Management products," University of Twente, 2009.

[19] United Nations Development Group, Results-Based Management. United Nations Development Group, 2011. 